\title{
The effect of dietary methyl branched-chain fatty acids on aspects of hepatic lipid metabolism in the rat
}

\author{
BY K. W. J. WAHLE AND W. R. HARE \\ Rowett Research Institute, Bucksburn, Aberdeen AB2 9SB
}

(Received 20 March 1981-Accepted 24 June 1981)

\begin{abstract}
1. Rats were fed to appetite on a stock laboratory diet or on diets consisting of the stock diet and in addition 50 or $200 \mathrm{~g}$ triolein $/ \mathrm{kg}, 50 \mathrm{~g}$ palmitic acid $/ \mathrm{kg}$ or $50 \mathrm{~g} / \mathrm{kg}$ of a concentrate mixture of methyl branched-chain fatty acids (Me-BCFA) which had been prepared from sheep adipose triacylglycerols.

2. No differences could be detected in the $\Delta 9$-desaturase activity or fatty acid synthetase activity of liver preparations from rats which had been fed on either the stock diet, the $50 \mathrm{~g}$ palmitic acid $/ \mathrm{kg}$ or the 50 and $200 \mathrm{~g}$ triolein $/ \mathrm{kg}$ diet; the palmitic acid diet was therefore taken as the control diet in subsequent experiments.

3. Rats consuming the $50 \mathrm{~g} \mathrm{Me}-\mathrm{BCFA} / \mathrm{kg}$ diet exhibited a marked reduction in the capacity of their liver microsomes for $\Delta 9$-desaturation when compared with animals receiving the control diet. The $\Delta 6$-desaturase activity also showed an inhibitory trend with the Me-BCFA diet.

4. Microsomal $\omega$-oxidation of fatty acids, mitochondrial succinate oxidation and the activity of cytosolic fatty acid synthetase (FAS) were unaffected by the ingestion of the Me-BCFA mixture compared with the diet which included palmitic acid.

5. There were no differences in the plasma concentrations of thyroxin, insulin and glucagon between animals fed on the diets containing palmitic acid or the Me-BCFA.

6. For a given concentration of fatty acids the Me-BCFA had a greater inhibitory effect when added to incubations of liver microsomes from rats fed on the standard diet than did the addition of palmitic acid.

7. The observations in vivo and in vitro strongly suggested that the Me-BCFA were having a specific inhibitory effect on the desaturation reaction.
\end{abstract}

Sheep and goats accumulate unusually high amounts of both odd-numbered fatty acids and a variety of methyl branched-chain fatty acids (Me-BCFA) in their adipose tissue triacylglycerols when fed on diets containing mainly cereal grain, particularly barley, wheat or maize (Garton et al. 1972; Duncan et al. 1974). Odd-numbered fatty acids are derived from propionate (Horning et al. 1961) and Me-BCFA from methylmalonate (Buckner $e t$ al. 1978; Scaife et al. 1978; Wahle \& Paterson, 1979; Wahle et al. 1979) which is the primary intermediate in the metabolism of propionate.

It is not known whether or to what extent the ingestion of moderate or large quantities of these Me-BCFA has any adverse effects on the metabolism of the recipient animals. When rats were given a concentrate of the mixture of Me-BCFA obtained from the adipose tissue triacylglycerols of barley-fed sheep, up to $100 \mathrm{~g} \mathrm{Me-BCFA} / \mathrm{kg}$ diet could be tolerated without apparent detriment to the animals and the Me-BCFA accumulated to various extents in different tissues (Smith et al. 1978). Rats given the concentrate of mixed Me-BCFA at $50 \mathrm{~g} / \mathrm{kg}$ diet had lower values for the ratio, 18:1:18:0 fatty acids in their liver triacylglycerols than did those given the same basal diet containing $50 \mathrm{~g}$ palmitic acid $/ \mathrm{kg}$ (A. Smith, A. K. Lough \& C. R. A. Earl, personal communication). Changes in the value $18: 1: 18: 0$ in the fatty acids of a tissue can reflect the activity of the $\Delta 9$-desaturase (Wahle, 1974).

Brett et al. (1971) have shown, using a series of ${ }^{14} \mathrm{C}$-labelled monomethyl-branched isomers of stearic acid, that a methyl branch between $\mathrm{C}-5$ and $\mathrm{C}-15$ prevented the substrate from being desaturated by the microsomal $\Delta$ 9-desaturase from rat liver. Similarly, Do \& Sprecher (1975), using a series of ${ }^{14} \mathrm{C}$-labelled branched-chain isomers of eicosa-8, 11 , 14-trienoic acid, also found that methyl branching between $\mathrm{C}-2$ and $\mathrm{C}-18$ hindered the 
$\Delta 5$-desaturation of the substrate in rat liver both in vivo and in vitro. However, these workers did not consider the possibility that dietary Me-BCFA could reduce the activity of the hepatic microsomal desaturase enzymes towards unbranched substrates. The present investigations are concerned primarily with the effect of dietary Me-BCFA on the activities of hepatic $\Delta 9$ - and $\Delta 6$-desaturases in the rat. A preliminary account of some of the findings has been published (Wahle \& Hare, 1980).

\section{MATERIAL AND METHODS}

\section{Animals and diets}

Rats of the Institute's Hooded Lister strain were fed ad lib. for $14 \mathrm{~d}$ on a standard laboratory diet ('Oxoid'; Herbert C. Styles (Bewdley) Ltd, Worcestershire) or on the standard diet which included $50 \mathrm{~g}$ palmitic acid, mixed Me-BCFA or triolein $/ \mathrm{kg}$ or $200 \mathrm{~g}$ triolein $/ \mathrm{kg}$. A concentrate of the mixed Me-BCFA was prepared from the adipose tissue triacylglycerols of barley-fed sheep (see Duncan et al. 1974) by procedures which removed unsaturated components by peroxidation and straight-chain saturated components by urea-adduct formation (Smith et al. 1979). The concentrate consisted of a complex mixture of saturated methyl-substituted fatty acids of chain length C-10-C-18 with $85-90 \%$ of the acids having chain lengths in excess of $\mathrm{C}-12$ and with the methyl substituents occurring on even-numbered $\mathrm{C}$ atoms. Mono-methyl and di-methyl-substituted fatty acids accounted for $56 \%$ and $23 \%$ of the total concentrate mixture respectively, which also contained $2 \%$ of tri-methylsubstituted fatty acids (Smith et al. 1979).

Details of the animals and their diets have been reported by Smith et al. (1979).

\section{Chemicals}

Chemicals and their sources have been given previously (Wahle, 1974). Analytical grade reagents were used throughout the investigation.

\section{Tissue preparations and assay procedures}

Hepatic microsomal and particle-free supernatant (PFS) preparations were obtained as described by Wahle (1974). Mitochondria were prepared by differential centrifugation in a medium containing $0.25 \mathrm{M}$-sucrose, $5 \mathrm{~mm}$-Tris-chloride and $1 \mathrm{~mm}$-EDTA at $\mathrm{pH} 7.2$ (Meyers \& Slater, 1957).

The extent of $\Delta 9$-desaturation of $\left[1{ }^{-14} \mathrm{C}\right]$ stearic acid was determined as described by Wahle (1974). $\Delta 6$-Desaturase activity towards $\left[1-{ }^{14} \mathrm{C}\right.$ linoleic acid was determined essentially as described by De Gomez-Dumm et al. (1978). The activity of fatty acid synthetase (FAS) was determined by a spectrophotometric assay procedure (Scaife $e t$ al. 1978).

The rate of state- 3 respiration of mitochondrial preparations in the presence of succinate as substrate (Chance \& Williams, 1955) was determined using a Clarke-type oxygen electrode with a Perspex chamber of $2.0 \mathrm{ml}$ capacity. Incubations were carried out at $25^{\circ}$ in a medium (pH 7.2) containing $100 \mathrm{~mm}$-potassium chloride, $10 \mathrm{~mm}$-HEPES (N-2-hydroxyethyl piperazine- $\mathrm{N}$-2-ethane sulfonic acid), $1 \mathrm{mg}$ bovine serum albumin $/ \mathrm{ml}$ and $38 \mathrm{~mm}$-sucrose with or without the addition of $10 \mu \mathrm{M}$-carbonyl cyanide $\mathrm{M}$ chlorophenylhydrazone (CCCP). Substrates were included at a final concentration of $5 \mathrm{~mm}$.

The microsomal $\omega$-oxidation of $\left[1{ }^{-14} \mathrm{C}\right]$ auric acid and $\left[1-{ }^{14} \mathrm{C}\right]$ palmitic acid was assayed essentially as described by Björkhem (1976).

Plasma insulin concentrations were determined by the method of Basset \& Thorburn (1971). Plasma glucagon was assayed using the procedure and antiserum supplied by Guildhay Antisera, Clinical Biochemistry Unit, University of Surrey, Guildford, Surrey. Plasma thyroxin levels were determined using kits supplied by Nuclear Medical Systems Inc., 1531 Monravia Avenue, Newport Beach, California. 
Table 1. $\Delta 9$-desaturase activity and fatty acid synthetase activity in liver preparations from rats receiving to appetite a standard diet or a standard diet supplemented with palmitic acid or triolein

(Mean values with their standard errors; no. of rats given in parentheses)

\begin{tabular}{|c|c|c|c|c|c|c|}
\hline & \multicolumn{3}{|c|}{$\begin{array}{l}\Delta 9 \text {-desaturase activity } \\
\text { (nmol oleate formed/ } \\
30 \mathrm{~min} \text { per mg protein) }\end{array}$} & \multicolumn{3}{|c|}{$\begin{array}{c}\text { Fatty acid synthetase activity } \\
\text { (nmol NADPH oxidized } \\
\text { min per mg protein) }\end{array}$} \\
\hline & Mean & & SE & Mean & & $\mathbf{S E}$ \\
\hline $\begin{array}{l}\text { Standard Oxoid } \\
\text { diet }\end{array}$ & 16.7 & $(4)$ & $1 \cdot 5$ & $20 \cdot 6$ & (5) & $1 \cdot 4$ \\
\hline $\begin{array}{l}\text { Standard }+50 \mathrm{~g} \\
\text { palmitic acid } / \mathrm{kg}\end{array}$ & $16 \cdot 2$ & (4) & 0.5 & $23 \cdot 3$ & (5) & 2.6 \\
\hline $\begin{array}{c}\text { Standard }+50 \mathrm{~g} \\
\text { triolein } / \mathrm{kg}\end{array}$ & 15.5 & (3) & $1 \cdot 0$ & - & & - \\
\hline $\begin{array}{l}\text { Standard }+200 \mathrm{~g} \\
\text { triolein } / \mathrm{kg}\end{array}$ & $16 \cdot 7$ & (3) & $2 \cdot 8$ & - & & - \\
\hline
\end{tabular}

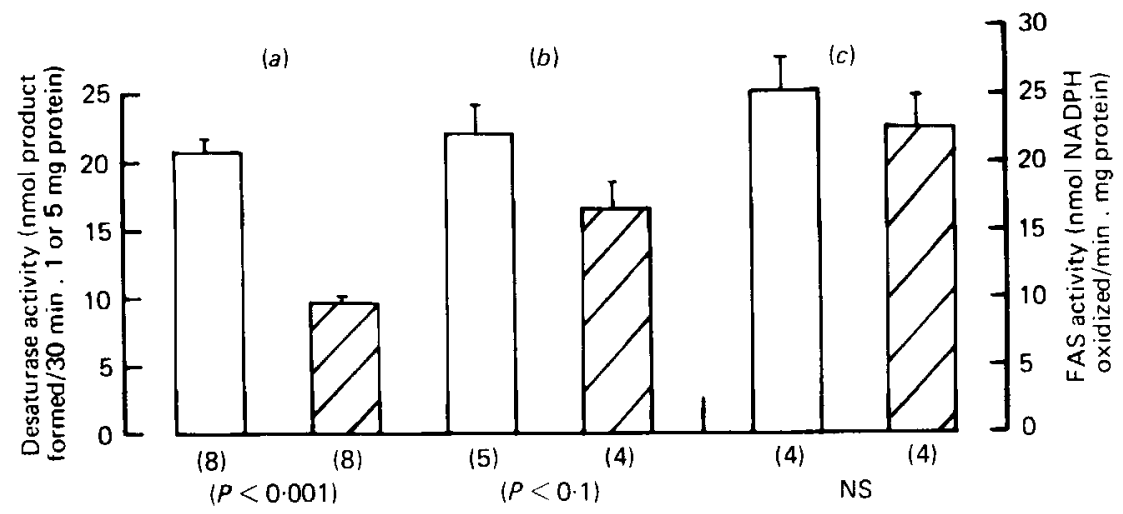

Fig. 1. (a) $\Delta 9$ - and (b) $\Delta 6$-desaturase and (c) fatty acid synthetase (FAS) activities in liver preparations from rats fed on either the control $(50 \mathrm{~g}$ palmitate $/ \mathrm{kg}$ ) diet $(\square)$ or the experimental $(50 \mathrm{~g}$ methyl branched-chain fatty acids (Me-BCFA) diet (疄). Values are means with their standard errors represented by vertical bars; no. of animals given in parentheses. NS, not significant.

\section{RESULTS}

The $\Delta$ 9-desaturase and FAS activity of liver preparations from rats given the standard diet which included $50 \mathrm{~g}$ palmitic acid $/ \mathrm{kg}$ did not differ from those of similar preparations from animals receiving only the standard diet (Table 1). Triolein at 50 or $200 \mathrm{~g} / \mathrm{kg}$ diet was also without effect on $\Delta 9$-desaturase activity. The diet which included $50 \mathrm{~g}$ palmitic acid $/ \mathrm{kg}$ was therefore taken as the control diet to which the effects of the $50 \mathrm{~g} \mathrm{Me}-\mathrm{BCFA} / \mathrm{kg}$ diet on the various aspects of hepatic metabolism under investigation were subsequently related.

Dietary Me-BCFA reduced the $\triangle 9$-desaturase activity of liver microsomes by approximately $50 \%(P<0.001)$ but was without significant effect on FAS activity; $\Delta$ 6-desaturase activity also showed a trend towards inhibition by dietary Me-BCFA $(P<0 \cdot 10)$ (Fig. 1$)$.

Addition of 50 and $100 \mathrm{nmol}$ mixed Me-BCFA to microsomes prepared from the livers of rats fed on the standard laboratory diet also had a greater inhibitory effect on their capacity for $\Delta 9$-desaturation of $\left[1-{ }^{14} \mathrm{C}\right]$ stearic acid than did the addition of the corresponding concentration of palmitic acid to the microsomes (Fig. 2). 


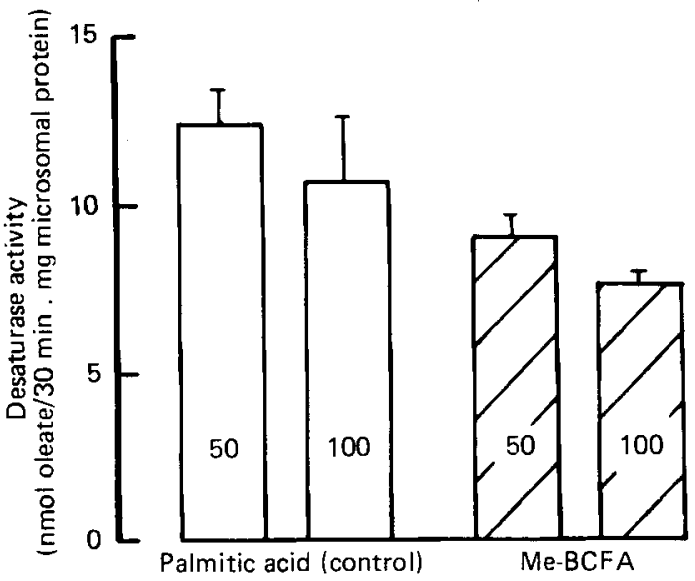

Fig. 2. $\Delta 9$-Desaturase activity in liver microsomes from rats fed on the standard laboratory diet. Effect of adding palmitic acid ( $\square$ ) or the mixture of methyl branched-chain fatty acids (Me-BCFA) (B) at concentrations of 50 and $100 \mathrm{nmol}$ to the standard desaturase incubation using $\left[1-{ }^{14} \mathrm{C}\right]$ stearic acid as substrate. Values are means with the standard errors for three animals.

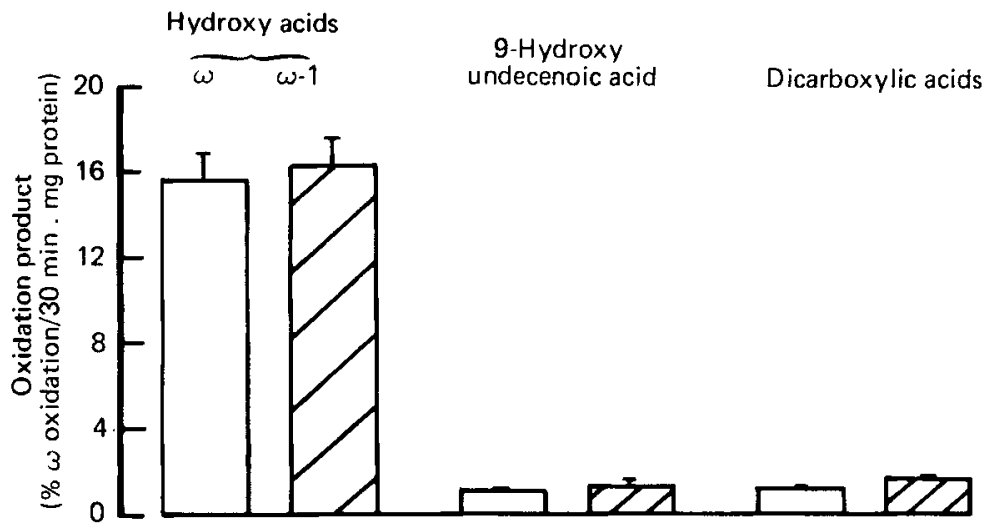

Fig. 3. Products of $\omega$-oxidation of $\left[1-{ }^{14} \mathrm{C}\right]$ auric acid by liver microsomes from rats fed on diets containing either $50 \mathrm{~g} / \mathrm{kg}$ palmitic acid ( $\square$ ) or $50 \mathrm{~g} / \mathrm{kg}$ methyl branched-chain fatty acids (图). Values are the means with the standard errors represented by vertical bars for four animals.

Table 2. Rates of oxidation of succinate by mitochondria from livers of rats fed on diets containing $50 \mathrm{~g}$ either palmitic acid or a mixture of $\mathrm{Me}-\mathrm{BCFA} / \mathrm{kg}$

(Mean values for four animals)

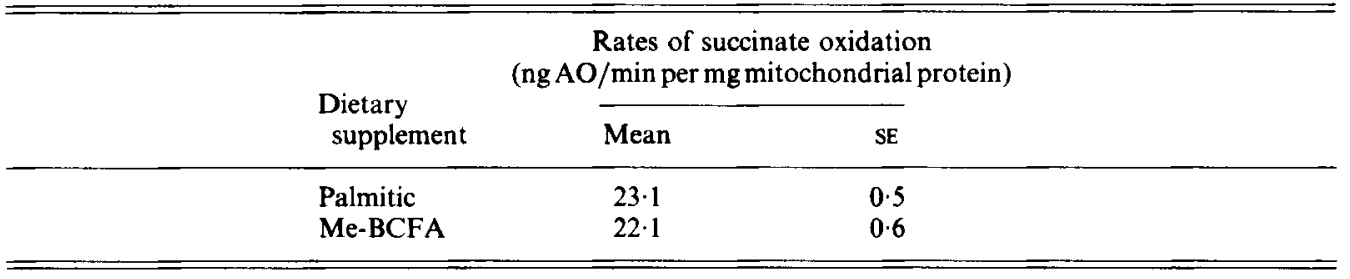

Me-BCFA, methyl branched-chain fatty acids; AO, atoms of oxygen. 
Table 3. Concentration of thyroxine, insulin and glucagon in blood plasma of rats fed on the standard oxoid diet supplemented with $50 \mathrm{~g} / \mathrm{kg}$ either palmitic acid or a concentrate mixture of $M e-B C F A$

(Mean values with their standard errors; no. of rats given in parentheses)

\begin{tabular}{|c|c|c|c|c|}
\hline & \multicolumn{2}{|c|}{ Palmitic acid } & \multicolumn{2}{|c|}{ Mixed Me-BCFA } \\
\hline & Mean & SE & Mean & SE \\
\hline Insulin $(\mu \mathrm{U} / \mathrm{ml})$ & $13 \cdot 1$ & $5 \cdot 8$ & $12 \cdot 4$ & 0.9 \\
\hline Glucagon $(\mathrm{pg} / \mathrm{ml})$ & $470 \cdot 2$ & 92.8 & $424 \cdot 5$ & $106 \cdot 0$ \\
\hline Thyroxine $(\mu \mathrm{g} / \mathrm{l})$ & 66 & 5 & 59 & 9 \\
\hline
\end{tabular}

Me-BCFA, methyl branched-chain fatty acids.

The microsomal $\omega$-oxidation of $\left[1^{14} \mathrm{C}\right]$ auric acid (and of $\left[1-{ }^{14} \mathrm{C}\right]$ palmitic acid; results not shown) was not affected by the donor animals having consumed the Me-BCFA diet (Fig. 3).

The mitochondrial oxidation of succinate also did not differ between liver preparations obtained from rats fed on the diet containing either $50 \mathrm{~g}$ palmitic acid or $50 \mathrm{~g} \mathrm{Me}-\mathrm{BCFA} / \mathrm{kg}$ (Table 2).

Plasma thyroxin, insulin and glucagon concentrations did not differ significantly between animals fed on either the palmitic acid or Me-BCFA diets (Table 3).

\section{DISCUSSION}

The desaturation and $\omega$-oxidation of fatty acyl-CoA and fatty acids respectively are closely related mono-oxygenase reactions which have a common requirement for certain components of a microsomal electron transport chain but utilize different terminal components of that chain (cf. Wahle \& Davies, 1977).

The marked inhibition of hepatic $\Delta$ 9-desaturase activity taken together with a similar inhibitory trend in the $\Delta 6$-desaturase activity and a complete lack of any effect on $\omega$-oxidase activity when the rats consumed diets containing Me-BCFA suggested that the inhibitory effect on desaturase activity was a specific one. The lack of any inhibition on the mitochondrial oxidation of succinate or the activity of cytosolic FAS by Me-BCFA further indicated that the observed inhibition of desaturase activity was unlikely to be due to alterations in the lipid environment of the membrane-bound mono-oxygenase system (Rouer et al. 1980) or to the general detergent properties of fatty acids (Pande \& Mead, 1970).

The possibility that the inhibitory effect of dietary Me-BCFA (high digestibility) might be due to differences in absorption from the intestinal tract of the rat is precluded by the findings that neither palmitic acid (low digestibility) nor triolein (high digestibility) had any significant effect on $\Delta 9$-desaturase activity. Previous work from this laboratory has also shown that sunflower-seed oil (high digestibility) at a concentration of $50 \mathrm{~g} / \mathrm{kg}$ diet did not influence $\Delta 9$-desaturase activity whereas $200 \mathrm{~g} / \mathrm{kg}$ markedly inhibited the enzyme activity (Wahle \& Radcliffe, 1977). Linoleic acid constitutes approximately $65 \%$ of the fatty acids of sunflower-seed oil and this acid is considered as having a specific and marked inhibitory effect on lipogenesis including $\Delta 9$-desaturase activity (Uchiyama et al. 1967; Inkpen et al. 1969; Musch et al. 1974). High concentrations of fatty acids in a tissue, 
including such saturated fatty acids as palmitic acid, have a general inhibitory effect on lipogenesis (cf. Romsos \& Leveille, 1974). However, since the FAS activity remained unchanged in animals fed on an Me-BCFA diet a general inhibitory effect of Me-BCFA can also be precluded. It would appear, therefore, that the Me-BCFA have a greater inhibitory influence on $\Delta 9$-desaturase activity than has previously been shown for either linoleic or oleic acids.

The suggestion of a specific inhibitory effect of the Me-BCFA is also supported by the observations in vitro when addition of Me-BCFA reduced the $\triangle 9$-desaturase activity to a greater extent than an equivalent concentration of palmitic acid when both were added in a soluble form in propylene glycol solution.

The lack of effect of the dietary Me-BCFA on plasma concentrations of glucagon, and in particular insulin and thyroxine, which are known to influence desaturase activity (Gellhorn \& Benjamin, 1964; Peluffo et al. 1971; Hoch et al. 1980), also precludes any involvement of these hormones in the observed inhibition of the desaturase enzymes by Me-BCFA.

The concentrate of mixed Me-BCFA used in these investigations contained fatty acids with methyl branches in the regions of the C chain (Smith et al. 1979) which, according to the observations of Brett et al. (1971) and Do \& Sprecher (1975) would be expected to prevent their desaturation by the stereospecific microsomal desaturases. It has been proposed that the impaired desaturation of Me-BCFA is the consequence of the methyl branches expanding the surface areas of the fatty acids in regions along the chain where unbranched fatty acids would normally be bound to the active sites of the enzymes, thereby rendering them inaccessible to enzyme action (Patil et al. 1979). Although the previouslymentioned findings offer an explanation for the decreased desaturation of certain Me-BCFA, why such Me-BCFA should impair the desaturation of unbranched fatty acids in not clear. The possibility exists that the Me-BCFA are bound to the enzyme in such a way that their expanded surface areas obstruct the access of unbranched fatty acids to the enzyme active sites. Such a mode of inhibition of $\Delta 9$-desaturase activity, both in vivo and in vitro, has been attributed to the cyclopropenoid fatty acids which have a cyclopropene ring structure in the vicinity of C-9 and C-10 of the hydrocarbon chain (Fogerty et al. 1972; Raju \& Reiser, 1973). Dietary or hormonal alterations of desaturase activity in a tissue are often associated with alterations in the amount of enzyme protein present in the tissue (Oshino \& Sato, 1972; Joshi \& Aranda, 1979). Therefore the possibility that Me-BCFA, or some metabolites thereof, might exert some effect on the synthesis of desaturase enzyme protein rather than exert a direct effect on existing enzyme proteins cannot be precluded at present.

The specific inhibitory effect of Me-BCFA on $\Delta 9$-desaturase activity without any obvious suppression of fatty acid synthetase activity does not support the conclusions of Jeffcoat et al. (1979) who stated that $\Delta 9$-desaturase activity plays an important role as a regulator of the fatty acid synthetase.

The authors gratefully acknowledge the help and advice of Drs A. K. Lough and A. Smith regarding the preparation of the diets and in providing some of the animals. The authors also wish to thank Messrs T. Atkinson and I. Grant for performing the hormone assays.

REFERENCES

Basset, J. M. \& Thorburn, G. D. (1971). J. Endocr. 50, 59

Björkhem. I. (1976). J. biol. Chem. 251, 5259.

Brett, D., Howling, D., Morris, L. J. \& James, A. T. 1971). Archs Biochem. Biophys. 143, 535.

Buckner, J. S., Kolattududy, P. E. \& Rogers, L. (1978). Archs Biochem. Biophys. 186, 152.

Chance, B. \& Williams, G. R. (1955). J. biol. Chem. 217, 383.

De Gomez-Dumm, I. N. T., de Alaniz, J. J. T. \& Brenner, R. R. (1978). Lipids 13, 649. 
Do, U. H. \& Sprecher, J. (1975). Archs. Biochem. Biophys. 171, 597.

Duncan, W. R. H., Orskov, E. R., Fraser, C. \& Garton, G. A. (1974). Br. J. Nutr. 32, 71.

Fogerty, A. C., Johnson, A. R. \& Pearson, J. A. (1972). Lipids 7, 335.

Garton, G. A., Hovell, F. E. DeB. \& Duncan, W. R. H. (1972). Br. J. Nutr. 28, 409.

Gellhorn, A. \& Benjamin, W. (1964). Biochim. biophys. Acta 84, 167.

Hoch, F. L. Depierre, J. W. \& Ernster, L. (1980) Eur. J. Biochem. 109, 301.

Horning, M. G., Martin, D. B., Karmen, A. \& Vagelos, P. R. (1961). J. biol. Chem. 236, 669.

Inkpen, C. A., Harris, R. A. \& Quackenbush, F. W. (1969). J. Lipid Res. 10, 227.

Jeffcoat, R., Roberts. P. A., Ormesher, J. \& James, A. T. (1979). Eur. J. Biochem. 101, 439.

Joshi, V. C. \& Aranda, L. P. (1979). J. biol. Chem. 254, 11779.

Meyers, D. K. \& Slater, E. C. (1957). Biochem. J. 67, 558.

Musch, K., Ojakian, M. A. \& Williams, M. A. (1974). Biochim. biophys. Acta. 337, 343.

Oshino, N. \& Sato, R. (1972). Archs Biochem. Biophys. 149, 369.

Pande, S. V. \& Mead, J. F. (1970). J. biol. Chem. 245, 1856.

Patil, G. S., Sprecher, J. \& Cornwall, D. G. (1979). Lipids 14, 826.

Peluffo, R. O., DeGomex-Dumm, J. N. T., De Alaniz, M. J. T. \& Brenner, R. R. (1971). J. Nutr. $101,1075$.

Raju, P. K. \& Reiser, R. (1973). J. Nutr. 103, 904.

Romsos, D. R. \& Leveille, G. A. (1974). Adv. Lipid Res. 17, 97.

Rouer, E., Dansette, P., Beaune, P. \& Leroux, J-P. (1980). Biochem. Biophys. Res. Comm. 95, 41.

Scaife, J. R., Wahle, K. W. J. \& Garton, G. A. (1978). Biochem. J. 176, 799.

Smith, A., Calder, A. G., Lough, A. K. \& Duncan, W. R. H. (1979). Lipids 14, 953.

Smith, A., Lough, A. K. \& Earl, C. R. A. (1978). Proc. Nutr. Soc. 37, 76A.

Uchiyama, M., Nakagawa, M. \& Okui, S. (1967). J. Biochem., Tokyo 62, 1.

Wahle, K. W. J. (1974). Comp. Biochem. Physiol. 48B, 87.

Wahle, K. W. J. \& Davies, N. T. (1977). J. Sci. Fd Agric. 28, 93.

Wahle, K. W. J., Duncan, W. R. H. \& Garton, G. A. (1979). Ann. Rech. Vet. 10, 362.

Wahle, W. W. J. \& Hare, W. R. (1980). Proc. Nutr. Soc. 39, 26 A.

Wahle, K. W. J. \& Paterson, S. M. (1979). Int. J. Biochem. 10, 433.

Wahle, K. W. J. \& Radcliffe, J. D. (1977). Lipids 12, 135. 